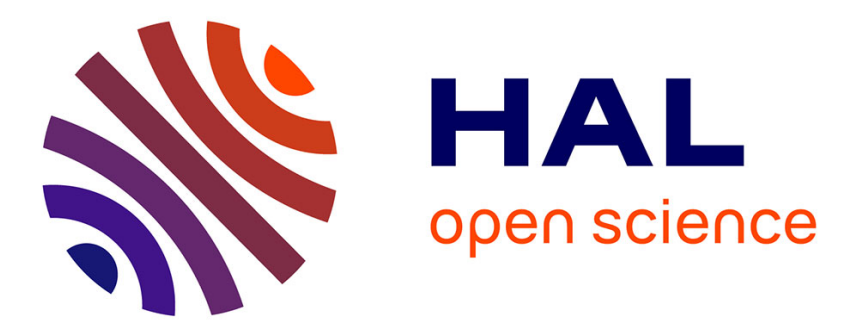

\title{
Pisiformectomy in advanced pisotriquetral joint arthritis: A retrospective study of 12 wrists with a mean follow-up of 7.5 years
}

\author{
Y.-K. de Almeida, C. Piessat, L. Athlani, F. Dap, G. Dautel
}

\section{To cite this version:}

Y.-K. de Almeida, C. Piessat, L. Athlani, F. Dap, G. Dautel. Pisiformectomy in advanced pisotriquetral joint arthritis: A retrospective study of 12 wrists with a mean follow-up of 7.5 years. Hand Surgery and Rehabilitation, 2019, 38, pp.165 - 168. 10.1016/j.hansur.2019.01.005 . hal-03484977

\section{HAL Id: hal-03484977 \\ https://hal.science/hal-03484977}

Submitted on 20 Dec 2021

HAL is a multi-disciplinary open access archive for the deposit and dissemination of scientific research documents, whether they are published or not. The documents may come from teaching and research institutions in France or abroad, or from public or private research centers.
L'archive ouverte pluridisciplinaire HAL, est destinée au dépôt et à la diffusion de documents scientifiques de niveau recherche, publiés ou non, émanant des établissements d'enseignement et de recherche français ou étrangers, des laboratoires publics ou privés.

\section{(c) (1) $\$$}

Distributed under a Creative Commons Attribution - NonCommerciall 4.0 International 
Pisiformectomy in advanced pisotriquetral joint arthritis: a retrospective study of $\mathbf{1 2}$ wrists with a mean follow-up of 7.5 years

\section{La pisiformectomie dans l'arthrose avancée de l'articulation piso-triquétrale : une étude rétrospective au recul moyen de 7,5 ans}

(1)

\section{Abstract}

Pisiformectomy is the gold standard treatment for pisotriquetral arthritis resistant to conservative treatment. We evaluated the long-term clinical and functional outcomes after pisiformectomy in resistant pisotriquetral arthritis cases.

We retrospectively evaluated 11 patients (12 wrists), mean age of 59 years (49-69) treated by pisiformectomy using a standardized surgical technique. Pisiformectomy was performed for primary osteoarthritis in 10 cases, for post-traumatic osteoarthritis in 1 case and for pisotriquetral instability in 1 case. The clinical and functional evaluation was carried out by an independent examiner.

Mean time to review was 90 months (63-151). Pain on a visual analog scale (/10) decreased significantly to 1.1 from 6.8 preoperatively. Mean range of motion was $79^{\circ}$ in flexion, $61.5^{\circ}$ in extension, $18^{\circ}$ in ulnar deviation and $36^{\circ}$ in radial deviation. Mean grip strength of the operated wrist was $86 \%$ of the non-operated wrist. Functional scores significantly improved with a gain of 40 points for the QuickDASH and 53 points for the PRWE.

Based on this long-term follow-up study, pisiformectomy seems to alleviate wrist pain and improve the quality of life in a low-demand population with pisotriquetral osteoarthritis resistant to conservative treatment. When compared to the pisotriquetral arthrodesis, pisiformectomy is easier to perform, allows quicker mobilization of the wrist and leads to good functional outcomes. 


\section{Résumé}

La pisiformectomie représente la solution chirurgicale la plus utilisée en cas d'échec d'un traitement médical bien conduit dans l'arthrose piso-triquétrale. L'objectif de cette étude était d'évaluer les résultats cliniques et fonctionnels à long terme de cette technique.

II s'agit d'une étude rétrospective monocentrique portant sur 11 patients (12 poignets), d'âge moyen 59 ans (49-69), opérés d'une pisiformectomie selon la même technique chirurgicale. Dans 10 cas, l'étiologie était l'arthrose piso-triquétrale essentielle. II y avait un cas d'arthrose post-traumatique et une instabilité de l'articulation piso-triquétrale. Une évaluation clinique et fonctionnelle a été réalisée par un examinateur indépendant. Le recul moyen à la révision était de 90 mois (63-151). On retrouvait une amélioration significative de la douleur avec une EVA moyenne évaluée à 1.1/10 (versus 6.8/10 en préopératoire). Les mobilités moyennes du poignet étaient de $79^{\circ}, 61,5^{\circ}, 18^{\circ}$ et $36^{\circ}$ en flexion, en extension, en inclinaison ulnaire et en inclinaison radiale respectivement. La force de poigne était de $86 \%$ par rapport au côté controlatéral. Les scores fonctionnels étaient également améliorés significativement avec un gain de 40 points pour le QuickDASH et 53 points pour le PRWE.

Au vu de cette étude au recul important, la pisiformectomie semble apporter l'indolence et améliorer le confort de vie chez les patients porteurs d'une arthrose pisotriquétrale avancée. En comparaison à l'arthrodèse piso-triquétrale, principale alternative chirurgicale, la pisiformectomie a l'avantage de la simplicité de réalisation, mais également des suites opératoires rapides permettant de maintenir les mobilités articulaires du poignet.

Key words: Arthritis; Pisiformectomy; Pisotriquetral joint

Mots-clés : Arthrose ; Pisiformectomie ; Articulation piso-triquétrale 


\section{Introduction}

The pisotriquetral joint (PTJ) is a rare and an often-overlooked cause of ulnar-sided wrist pain. Causes of pisotriquetral dysfunction are primary osteoarthritis (Fig. 1), posttraumatic osteoarthritis (Fig. 2) and PTJ instability after carpal tunnel release [1]. Surgical management is indicated in resistant cases after well-conducted conservative treatment. The most used surgical options for PTJ osteoarthritis are pisiformectomy and pisotriquetral fusion [2-8].

Functional and clinical results after pisiformectomy are rarely reported in the literature. Almost all authors describe generally favorable outcomes with pain relief and no loss of wrist motion. However, results for grip strength are contradictory [2-7]. In a recent biomechanics study, O'Keefe et al. [9] demonstrated that greater flexor carpi radialis (FCU) force was required to flex the wrist after pisiformectomy in cadaver model. They concluded that FCU force decreased by $20 \%$ in the extreme range of motion and during fast movements.

The objective of our retrospective study was to report the long-term clinical and functional outcomes after pisiformectomy.

\section{Patients and methods}

2.1. Population

From 2005 to 2012, 14 patients (15 wrists) with a mean age of 59 years (48-69) were operated at our hospital. Pisiformectomy was performed for primary osteoarthritis in $83 \%$ and post-traumatic osteoarthritis in $17 \%$. All patients were included retrospectively.

\subsection{Surgical technique}

Pisiformectomy was performed by five senior hand surgeons. The surgical technique was standardized and consisted in a V-shaped approach of the pisiform. The FCU sheath was incised longitudinally to avoid damaging the ulnar neurovascular bundle. The next step was to confirm PTJ arthritis before pisiform excision. The longitudinal tenotomy of the FCU was closed with a slow resorbing running suture. The skin was closed with absorbable 
sutures without the use of a drain. X-rays were taken systematically, and the patients wore a cast with the wrist in neutral position for 15 days.

2.3. Clinical evaluation

Patients were contacted for a clinical and functional evaluation of the operated wrist. A questionnaire was mailed to patients who could not easily return for the review visit.

Clinical evaluation criteria were pain at rest on a visual analog scale (VAS, /10), grip strength (Kg.F) with the Jamar® hydraulic gauge (Arex ${ }^{\mathrm{TM}}$, Palaiseau, France), and wrist motion in flexion, extension, radial and ulnar deviation. These data were compared to the contralateral wrist. FCU instability was evaluated by moving the wrist passively in flexion/extension and ulnar deviation. Sensation was evaluated with the Weber two-point discrimination test (millimeter) of the fifth finger.

Functional results were determined using the standardized QuickDASH (Disabilities of the Arm, Shoulder and Hand Score, /100) and PRWE (Patient-Rated Wrist Evaluation, /100) [10-11] scores. Ulnar neuritis was evaluated with the DN4 questionnaire [12]. A score of 4/10 or higher was considered positive. Scar pain was evaluated by palpating the ulnar side of the hand. The activity level after pisiformectomy was compared with the presurgery level (less, equal, more). Finally, patients were asked to rate their satisfaction ("poor", "moderate", "good" or "excellent"). Clinical and functional evaluations was carried by an independent examiner.

\subsection{Statistical analysis}

Data were compared using the paired Student's $t$ test at a significance level of $p$ $<0.05$.

\section{Results}



total wrist fusion (two cases) before the pisiformectomy procedure. Total wrist fusion was performed after failure of proximal row carpectomy and pisiformectomy was performed because of piso-ulnar impingement. Four-corner fusion was indicated for a SLAC (ScaphoLunate Advanced Collapse) wrist. Finally, 11 patients (12 wrists) were included in our analysis, of which two patients answered via a questionnaire only. The dominant hand was involved in $67 \%$. Eight patients $(67 \%)$ were retired. Four patients $(33 \%)$ had a carpal tunnel release before the pisiformectomy. Mean time to final review was 90 months (63-151) (Table 1).

At the final review, pain on VAS was significantly reduced $(p<0.001)$ from $6.8 / 10$ preoperatively to $1.1 / 10$. Grip strength was $23 \mathrm{~kg}$.F, which was $80 \%$ of the contralateral wrist grip $(p=0.07)$. Mean range of motion was $79^{\circ}, 61.5^{\circ}, 36^{\circ}$ and $18^{\circ}$ or $97 \%, 86 \%, 97 \%$ and $92 \%$ compared to the contralateral side in flexion, extension, ulnar deviation and radial deviation, respectively. All but extension $(p=0.006)$ were not significantly decreased compared to the contralateral side. One patient reported having FCU instability. The mean Weber two-point discrimination test was $3.5 \mathrm{~mm}$ and ranged from 2 to $6 \mathrm{~mm}$ at the fifth fingertip.

The QuickDASH and PRWE improved significantly at the final review visit with a gain of 40 points and 53 points, respectively $(p<0.005)$.

TheDN4 score was positive in three cases (25\%). However, all these patients had preoperative symptoms of neuritis of the ulnar nerve according to the surgeon's preoperative findings (DN4 not done before surgery). Two patients (7\%) complained of ulnar pain at the wrist with scar tenderness. The level of activity was improved in 10 patients (83\%) and similar in two patients (17\%). The overall outcome was rated as "good" or "excellent" in all cases (Table 2).

\section{Discussion}



conservative treatment. Our study seems to confirm the good long-term results of pisiformectomy on pain and functional outcomes. Our results are similar to those reported in the literature. In 1978, Helal [2] reported on four racket-sport players complaining of ulnarsided pain of the wrist due to chondromalacia. A painless wrist was obtained after pisiformectomy in all cases and all returned to their prior sports level. Other authors also concluded that pisiformectomy was effective at providing pain relief [3-7].

Van Eijzeren et al. [6] and Lam et al. [7] reported no difference in grip strength compared to the non-operated wrist in their case series of 11 patients (mean age of 47 years) and 19 patients (mean age of 45 years) respectively. Trail et al. [4], in a case series of 12 patients (mean age of 31 years), reported significantly decreased grip strength (86\% of the contralateral wrist).

O'Keefe et al [9], in a biomechanical study, found greater FCU excursion in extreme range of motion after pisiformectomy and while carrying heavy loads because the pisiform acts as a pulley. Increasing the FCU excursion leads to decreased FCU force during these tasks.

Our results are similar to these studies with significant pain reduction and better functional scores with a loss of grip strength. However, patients did not complain about this loss of strength and the painless wrist was stable over the long term. We found no cases of iatrogenic ulnar neuritis. The DN4 score was negative except in patients complaining of ulnar neuritis before the pisiformectomy. The Weber two-point discrimination test found no evidence of fingertip hypoesthesia.

PTJ arthritis can be primary, post-traumatic (fracture or ligament injury) or the result of pisiform instability after flexor retinaculum release [1]. Interestingly, four patients (33\%) presented with PTJ pain a few months after carpal tunnel release. We hypothesize that sectioning this strong stabilizer (flexor retinaculum) could trigger PJT instability that might reveal underlying PTJ arthritis or accelerate the development of PTJ arthritis. Nevertheless, 
Legré et al. [13], in a retrospective study of 55 patients undergoing minimally invasive carpal tunnel release, did not find PTJ instability.

PTJ arthrodesis is an alternative to pisiformectomy. This procedure is preferred by some authors $[8,14]$ for young patients to prevent loss of grip strength. Nevertheless, this technique requires extensive experience, a small surface area for bone healing and longterm casting. Abrams et al. reported on a 14-year-old female gymnast complaining of PTJ instability [8]. PTJ fusion was performed and painless wrist was obtained but she complained of her wrist freezing in maximum flexion. Singer et al. performed PTJ fusion in a 22-year-old male cyclist with painful PTJ instability [14]; a painless wrist was obtained with full range of motion. Unfortunately, grip strength was not mentioned in both of these case reports.

Recently, Bellemère et al. [15] reported good results with pyrocarbon implant interposition (Pyrocardan®, Tornier ${ }^{\mathrm{TM}}$, Grenoble, France) in eight patients with a symptomatic primary PTJ osteoarthritis. Painless wrist was obtained in all patients with a $95 \%$ range of motion in flexion-extension compared to the contralateral wrist and no loss of grip strength. One implant dislocated and was successfully treated surgically by repositioning the implant with a Gore-Tex suture. Outcomes were favorable with early return to work.

\section{Conclusion}

Given the results of this study, pisiformectomy appears to yield good clinical and functional outcomes over many years. Grip strength was not significantly decreased but only 12 cases were available for evaluation. The simplicity of pisiformectomy and early mobilization make this operation a valuable option for advanced, recalcitrant PTJ osteoarthritis regardless of its etiology.

\section{Conflict of interest:}

The authors declared no potential conflicts of interest with respect to the research, authorship, and/or publication of this article. 
Informed consent: The participants had given informed consent for the study.

\section{References}

1. Le Nen D, Saraux A, Dubrana F, Lefèvre C. Pathologie de l'articulation pisotriquétrale, Démembrement à propos de 26 cas. Ann Orthop Ouest 2000;32:129-34.

2. Helal B. Racquet player's pisiform. Hand 1978;10:87-90.

3. Carroll RE, Coyle MP Jr. Dysfunction of the pisotriquetral joint: treatment by excision of the pisiform. J Hand Surg Am 1985;10:703-7.

4. Trail IA, Linscheid RL. Pisiformectomy in young patients. J Hand Surg Br 1992;17:346-8.

5. Pierre A, Le Nen D, Hu W, Dubrana F, Saraux A, Chaise F. Traitement des douleurs piso-triquétrales par exérèse du pisiforme : à propos de 15 cas. Chir Main. 2003;22:37-42. 6. Lam KS, Woodbridge S, Burke FD. Wrist function after excision of the pisiform. J Hand Surg Br 2003;28:69-72.

7. Van Eijzeren J, Karthaus RP. The effect of pisiform excision on wrist function. J Hand Surg Am 2014;39:1258-63.

8. Abrams R, Tontz W. Pisotriquetral arthrodesis as an alternative to excision for pisotriquetral instability in high demand patients: a case report in a gymnast. J Hand Surg Am 2006;31:611-4.

9. O'Keefe KD, Werner FW, Boyette M, Palmer AK, Garcia-Elias M, Harley BJ. Effect of pisiform excision or pisotriquetral arthrodesis as a treatment for pisotriquetral arthritis: a biomechanical study. J Hand Surg Am 2013;38:1913-18. 10. Hudak PL, Amadio PC, Bombardier C. Development of an upper extremity outcome measure: the DASH (disabilities of the arm, shoulder and hand). The Upper Extremity Collaborative Group (UECG). Am J Ind Med 1996;29:602-8. 86. 
219 12. Bouhassira D, Attal N, Alchaar H, Boureau F, Bruxelle J, Cunin G, et al. Comparison 220 of pain syndromes associated with nervous or somatic lesions and development of a new 221 neuropathic pain diagnostic questionnaire (DN4). Pain 2005;114:29-36.

222 13. Caubère A, Butin C, Guilhem K, Levadoux M, Legré R, Nguyen MK. Is there 223 pisotriquetral instability after carpal tunnel release? Retrospective study of 55 cases. Chir 224 Main 2014;33:286-90.

225 14. Singer G, Eberl R, Hoellwarth ME. Pisotriquetral arthrodesis for pisotriquetral 226 instability: case report. J Hand Surg Am 2011;36:299-303.

227 15. Bellemère $\mathrm{P}$, Aribert $\mathrm{M}$, Choughri $\mathrm{H}$, Leroy $\mathrm{M}$, Gaisne $\mathrm{E}$. Treatment of pisotriquetral 228 arthritis by pyrocarbon interposition arthroplasty. J Wrist Surg 2018;7:2-20. 


\section{Figure captions}

231 Fig. 1. X-rays of primary pisotriquetral joint (PTJ) osteoarthritis (wrist in $30^{\circ}$ supination)

232 Fig. 2. T2-weighted magnetic resonance imaging of a case of post-traumatic PTJ

233 osteoarthritis due to PTJ instability with rupture of the pisohamate ligament (ulnar deviation 234 of the pisiform)

235

236 Table titles

237 Table 1. Characteristics of the study population (both wrists were operated in patient 1).

238 POA: primary $\mathrm{OA}$

239 Table 2. Clinical and functional outcomes after pisiformectomy (two patients were contacted 240 by mail). VAS: visual analog scale 


\section{FIGURES}

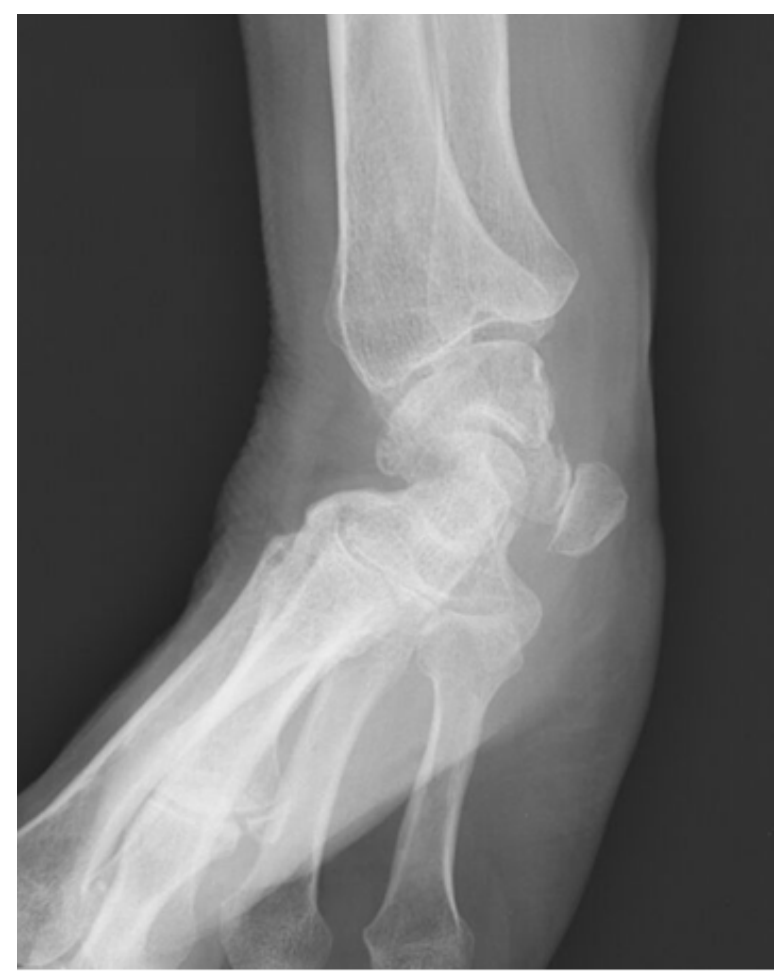

Fig. 1. X-rays of primary pisotriquetral joint (PTJ) osteoarthritis (wrist in $30^{\circ}$ supination)

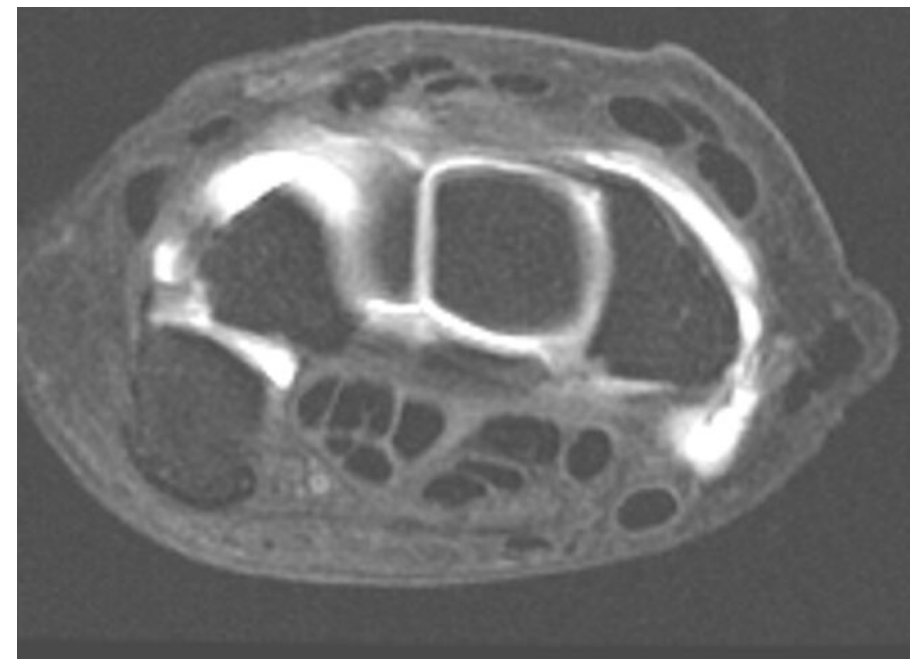

Fig. 2. T2-weighted magnetic resonance imaging of a case of post-traumatic PTJ osteoarthritis due to PTJ instability with rupture of the pisohamate ligament (ulnar deviation of the pisiform) 


\section{TABLES}

Table 1. Characteristics of the study population (both wrists were operated in patient 1). POA : primary osteoarthritis

\begin{tabular}{|c|c|c|c|c|c|c|c|c|c|c|c|}
\hline Patient & 1 & 2 & 3 & 4 & 5 & 6 & 7 & 8 & 9 & 10 & 11 \\
\hline Age & 66 & 64 & 52 & 69 & 48 & 55 & 53 & 64 & 62 & 57 & 52 \\
\hline Etiology & POA & POA & Traumatic & POA & Traumatic & POA & POA & POA & POA & POA & POA \\
\hline $\begin{array}{l}\text { Affected } \\
\text { wrist }\end{array}$ & Bilateral & Right & Right & Right & Right & Left & Right & Left & Right & Right & Right \\
\hline $\begin{array}{l}\text { Dominant } \\
\text { hand }\end{array}$ & Right & Left & Right & Right & Right & Right & Right & Right & Right & Right & Right \\
\hline $\begin{array}{l}\text { Ulnar nerve } \\
\text { neuritis }\end{array}$ & - & - & + & - & $\begin{array}{l}\text { + (severe } \\
\text { cubital } \\
\text { tunnel } \\
\text { syndrome) }\end{array}$ & + & - & - & + & - & - \\
\hline Occupation & Retired & Retired & $\begin{array}{l}\text { Manual } \\
\text { labor }\end{array}$ & Retired & Retired & Retired & Retired & $\begin{array}{l}\text { Office } \\
\text { worker }\end{array}$ & $\begin{array}{l}\text { Office } \\
\text { worker }\end{array}$ & Retired & $\begin{array}{l}\text { Office } \\
\text { worker }\end{array}$ \\
\hline $\begin{array}{l}\text { Anterior } \\
\text { carpal } \\
\text { tunnel } \\
\text { release } \\
\text { (delay in } \\
\text { months) }\end{array}$ & $\begin{array}{l}\text { Yes (15 } \\
\text { and } 23)\end{array}$ & No & No & No & No & No & $\begin{array}{l}\text { Yes (wrist } \\
\text { pain } \\
\text { before } \\
\text { carpal } \\
\text { tunnel } \\
\text { release) }\end{array}$ & No & Yes (24) & Yes (4) & No \\
\hline
\end{tabular}


Table 2. Clinical and functional outcomes after pisiformectomy (two patients were contacted by mail). VAS: visual analog scale

\begin{tabular}{|c|c|c|c|}
\hline & Preoperative status & Postoperative status & $p$ value \\
\hline Pain at rest (VAS, /10) $(n=11)$ & 6.8 & 1.1 & $<0.005$ \\
\hline QuickDASH score /100 (n=11) & 68.4 & 27.6 & $<0.005$ \\
\hline PRWE score /100 (n=11) & 75.4 & 22.1 & $<0.005$ \\
\hline DN4 score /10 (n=11) & / & 1.7 & \\
\hline Flexor carpi ulnaris instability ( $n=9$ ) & / & 1 & \\
\hline \multirow[t]{2}{*}{ Weber two-point discrimination test $(\mathrm{mm})(\mathrm{n}=9)$} & / & 3.5 & \\
\hline & Operated wrist $(n=9)$ & $\begin{array}{l}\text { Contralateral wrist ( } n=7 \\
\text { because one patient was } \\
\text { operated on both side) }\end{array}$ & \\
\hline Flexion $\left({ }^{\circ}\right)$ & 79.5 & 82.5 & 0.05 \\
\hline Extension $\left({ }^{\circ}\right)$ & 61.5 & 71.5 & 0.006 \\
\hline Ulnar deviation $\left({ }^{\circ}\right)$ & 18 & 19.5 & 0.19 \\
\hline Radial deviation $\left({ }^{\circ}\right)$ & 36 & 37 & 0.17 \\
\hline Wrist grip strength (kg.F) & 22.9 & 28.9 & 0.07 \\
\hline
\end{tabular}


